
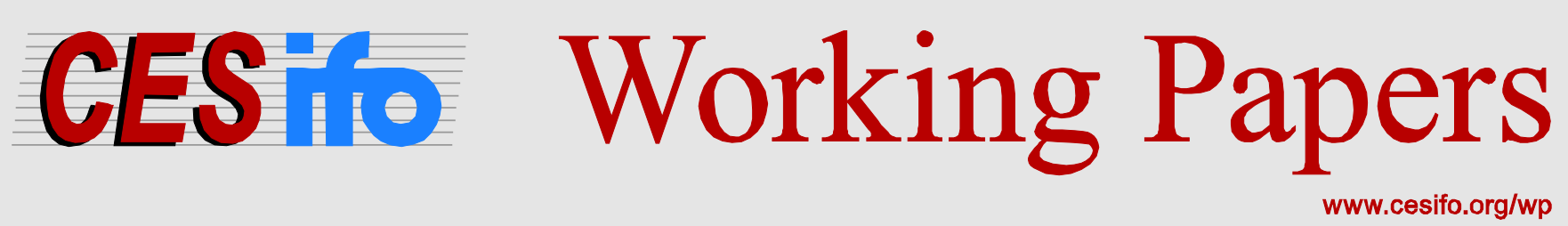

\title{
Institutional Architecture for Financing Pan-Asian Infrastructure Connectivity
}

\author{
Biswa Nath Bhattacharyay \\ Madhurima Bhattacharyay
}

\author{
CESIFO WORKING PAPER NO. 6422 \\ CATEgory 7: Monetary POLICY and InTERnational FinanCE \\ MARCH 2017
}

An electronic version of the paper may be downloaded

- from the SSRN website:

- from the RePEc website:

- from the CESifo website:

WwW.SSRN.com

www.RePEc.org

www.CESifo-group.org/wp

\section{CESifo}




\title{
Institutional Architecture for Financing Pan-Asian Infrastructure Connectivity
}

\begin{abstract}
Asia, particularly its major economies has witnessed slower growth in recent years. To make Asia more economically sustainable and resilient against external shocks to recover from the falling growth, most regional economies need to rebalance their export-oriented (mostly to advanced economies) production and growth towards Asian markets and regional demand, and trade-driven growth through increased intraregional infrastructure connectivity and regional economic integration. In 1992, a pan-Asian transport connectivity was initiated through, Asian Highway Network and Trans-Asian Railways Network. In 2015, an ambitious pan-Asian connectivity initiative, namely "One Belt, One Road" (ancient silk road) initiative has been proposed. This initiative plans to create an economic zone covering Asia, Europe and Africa. To successfully promote and finance greater physical connectivity, at the pan-Asian, sub-regional and national levels, Asia will require a strong and appropriate institutional framework for effective coordination, cooperation and collaboration among national, subregional, and regionwide institutions as well as other stakeholders. This paper discusses the prospects and challenges facing Asian connectivity as well as infrastructure financing needs in Asia. It also examines the nature and characteristics of existing and new institutions and the emerging role of regional and international institutions for enhancing Asian connectivity. Lastly, it proposes an institutional architecture consisting of new "Asian Infrastructure Coordination Facility (AICF)” involving major stakeholders for building a seamless pan-Asian connectivity through bilateral, regional and international cooperation, partnership and collaboration in infrastructure development.
\end{abstract}

JEL-Codes: R100, R400, R420.

Keywords: Asia, connectivity, hard and soft infrastructure, bilateral, regional and international institutions, inclusive and sustainable infrastructure, infrastructure financing, institutional architecture, financial instruments, bilateral and multilateral development banks.

\author{
Biswa Nath Bhattacharyay \\ Asian Development Bank \\ Manila / Philippines \\ dr_biswa@yahoo.com
}

\author{
Madhurima Bhattacharyay \\ Desautels Management School \\ McGill University / Montreal / Canada \\ madhurima.bhattacharyay@mail.mcgill.ca
}




\section{Introduction}

Infrastructure connectivity plays a key role in promoting and sustaining rapid economic growth. Properly designed infrastructure can also make growth more inclusive by sharing its benefits with poorer regions, groups and communities, especially by connecting remote and poor areas of a country and small and landlocked countries to major business centres. Infrastructure can also be environmentally sustainable through utilizing appropriate technology, procedures and systems for clean and renewable energy development and for resource efficiency. The Asia-Pacific region has witnessed good progress in infrastructure development, however, the growth of infrastructure lags behind its economic, urban and population growth. Furthermore, quantity and quality of infrastructure lags behind international standards. Inadequate and poor infrastructure can hamper the potential economic growth of Asian countries, weaken their international competitiveness, and adversely affect their poverty reduction efforts.

As an aftermath of global financial crisis of 2008 and ongoing European debt crisis, major economies, particularly advanced economies such as US, Europe and Japan are witnessing slow growth and even recession with shrinking consumption. In spite of very accommodative monetary policies of near-zero interest rates and non-conventional monetary policy of "Quantitative Easing" in North America, Europe and Japan, global economic growth remains very low. In this situation, infrastructure investment in large national and regional projects through fiscal stimulus and private sector investment can enhance economic growth.

Furthermore, major Asian economies, particularly China, Japan and South Korea have witnessed slower growth in recent years. To make Asia more economically sustainable and resilient against external shocks to recover from the falling growth, most regional economies need to rebalance their export-oriented (mostly to advanced economies) production and growth towards Asian markets and regional demand, and trade-driven growth through increased intraregional infrastructure connectivity and regional economic integration.

Furthermore, large national and regional infrastructure projects involving several Asian economies have great potential to act as new engines for promoting growth and creating jobs. Such projects inherently include expanded employment opportunities and increased investment, not only in the project itself, but also in secondary and supporting industries and supply chains. Enhancing infrastructure connectivity across and beyond Asia could increase national and regional competitiveness and productivity, speed up economic recovery, and assist in achieving balanced and inclusive growth in the medium to long-term. Furthermore, green connectivity could enhance environmental sustainability through the development of appropriate cross-border green energy and transport networks.

The effectiveness of connectivity depends on the quantity and quality of hard and soft infrastructure. Of particular importance in terms of soft infrastructure which makes hard infrastructure work effectively are the facilitating institutions that support connectivity through formulating and implementing appropriate policies, rules, regulations, reforms, systems, practices and procedures; and promoting effective coordination and cooperation. To successfully promote greater pan-Asia physical connectivity, Asia needs to develop effective national, subregional, and region-wide institutions and innovative financial instruments and mechanisms taking into account its great diversities. In addition, an appropriate institutional framework needs to be established for effectively identifying, designing, and implementing national and regional infrastructure projects through proper coordination among various stakeholders.

Furthermore, Asia faces a huge infrastructure financing needs of around $\$ 750$ billion per year on an average in coming years (Bhattacharyay, 2012a). Many Asian countries are not capable of meeting this large financing need, particularly in view of their fiscal constraints. 
New regional and international institutions like "Asia Infrastructure Investment Bank" (AIIB) and "New Development Bank" (NDB) or "BRICS Bank" have been established in 2015 to fill in the infrastructure financing gap.

As Asia's integration has been primarily market-led and its institutional arrangements for infrastructure cooperation are fragmented at subregional levels, a new and strong regional Asian approach to pan-Asian connectivity is required with subregional cooperation institutions as building blocks. Bottom-up, and market-driven cooperation needs to be complemented by top-down cooperation led by leaders at the highest level, and institutionalized.

The international, regional and bilateral institutions play a crucial role in enhancing connectivity in various ways, particularly through promoting increased regional and international cooperation, mobilizing finance and developing capacity of less developed countries. Asia has many overlapping subregional and regional institutions involved in national and regional energy, transport, water and telecommunications infrastructure connectivity projects. However, most of these sub-regional institutions involved in regional or cross-border infrastructure development are characterized as being less effective, informal, and lacking a clear and binding system of rules and policies. The present institutional structure in Asia is neither adequate nor effective in addressing various challenges confronting infrastructure development.

In recent time, the international and regional financial markets have witnessed a turbulent and volatile period dampening private sector confidence in long-term financing. As the international and regional financial markets shrink, a corresponding decline in infrastructure and trade financing will occur. A major priority for developing Asian countries is to find ways and means to mobilize its huge savings to fund its infrastructure development.

In view of the above, it is of urgent importance to study the role of regional and international institutions in financing Asian connectivity and the need for an appropriate institutional architecture for enhancing Asian infrastructure connectivity.

This paper examines (i) the prospects and challenges facing Asian connectivity, (ii) the nature, structure and characteristics of existing and new institutions for connectivity, (iii) the emerging role of regional and international institutions for enhancing Asian connectivity and (iv) the prospect of a new institutional architecture involving major stakeholders for building a seamless Asian connectivity through national, bilateral, regional and international cooperation in infrastructure development. It also proposes and discusses the organizational structures and functions of a new "Asian Infrastructure Coordination Facility (AICF)" under this new institutional architecture.

\section{Asian Connectivity: Prospects and Challenges}

The concept of connectivity in this paper is the creation of physical and nonphysical facilitating linkages within the region through the development of required infrastructure to enable the free movement of goods, persons, services, technology and ideas across the region. Physical connectivity is essential for the smooth and cost-effective flow of goods and services within Asian economies and across Asian borders. This will require physical, or "hard," infrastructure, such as transport (roads, rail lines, airports, and seaports), energy (oil and gas pipelines, and electricity grids), and telecommunications (cross-border fiber optic cables and broadband internet); as well as facilitating, or "soft," infrastructure, such as appropriate policies (e.g., trade facilitation policies such as effective border and customs procedures for smooth flow of people, services and goods into and out of the country); and, effective laws and regulations, systems and procedures; and institutions to make hard infrastructure work properly (Bhattacharyay, 2010). 


\subsection{Concept and Benefits of Asian connectivity}

Bhattacharyay (2010) discussed the various dimensions of the concept and benefits of Asian connectivity:

- Creating a Seamless Asia-a physically, economically, and financially integrated region connected by world-class, efficient, and environment-friendly infrastructure networks in transport, energy, water, and telecommunications that

(i) rebalances Asia's export-oriented growth

(ii) promotes trade and investments within the region and with global markets,

(iii) widen access to markets and public services and

(iv) thereby promote inclusive and sustainable economic growth and reduce poverty;

- Expanding, deepening, and increasing the efficiency of regional production network and supply chains by digitizing communications and logistics, streamlining policies, systems and procedures such as customs procedure and other bureaucratic impediments;

- Developing efficient regional financial markets, particularly bond markets that channel savings from around Asia and the rest of the world in to productive investments and industries, notably infrastructure throughout the region; and

- Developing efficient, sustainable, adequate, affordable, safe, accessible and seamless connections across Asia and with the rest of the world to create a more competitive, prosperous, and integrated region, and to utilize Asia's enormous untapped economic potential.

Large infrastructure investment for enhancing connectivity can enhance economic growth, and generate significant jobs. At the same time, it can meet the basic needs of people such as electricity, transport and water, and offer an alternative asset class with good returns for private sector investors particularly in the prevailing low yield financial environment, and at the same time.

Based on time series data, it is estimated by a recent CITI GPS report that every $1 \%$ increase in infrastructure investment can cause a 1.2\% increase in GDP growth (Citi GPS, 2016). This clearly shows the importance of infrastructure investment to increase economic growth.

Physical connectivity, particularly transport connectivity is not new to Asia. The ancient silk route of Asia was the world's most important cross-border artery until the 13th century, when Asia was the most important trade and economic center of the world. The silk road was an extensive interconnected network of trade routes across the Asian continent connecting East, South, Central, and Western Asia with the Mediterranean world, as well as North Africa and Europe (Bhattaharyay and De 2009).

\subsection{Regional Infrastructure Projects for Connectivity}

Regional or cross-border transport infrastructure is found to be one of the major determinants of the economic integration process (Vickerman 2002). Transport network strengthens international (and regional) connectivity through the free flow of goods and factors across borders, assisting countries to benefit from a more optimal allocation of resources. A transportation network linking neighbouring countries, in general, enhances market size and facilitates national economies to grow further through higher trade and production (Bhattaharyay and De, 2009). Decreasing communication and transport costs together with the technological development could enhance countries' comparative 
advantages (Krugman 1991). In this highly globalized world, national comparative advantages may be wiped out unless complemented by regional comparative advantages such as regional physical connectivity.

\subsubsection{Asian Highway and Railway Connectivity}

In 1992, a pan-Asian transport connectivity program was initiated by UNESCAP through ambitious projects, namely Asian Highway Network and Trans-Asian Railways Network. The goal of Asian Highway is to strengthen economic and $r=$ trade links among Asia, Europe and the Middle East through the development of $141271 \mathrm{~km}$ standardized highways-including 155 regional roads involving 32 Asia countries. The Trans-Asian railways aims to link panAsian and pan-European rail networks at various location, connecting major ports of Asia and Europe and facilitating landlocked countries with improves access to seaports either directly or inc conjunction with highways(UNESCAP 2010).

\subsubsection{One Belt, One Road Project}

Recently, in order to rebuild "the $13^{\text {th }}$ Century Silk Route" connecting Europe and Asia, China proposed on 7 September, 2013 a new pan-Asian connectivity strategy, namely "One Belt, One Road" strategy------ "the Silk Road Economic Belt" and the "21st Century Maritime Silk Road" which will create an economic zone covering Asia, Europe and Africa, connecting China with the Persian Gulf and the Mediterranean Sea through Central Asia and West Asia (Kiernan, 2015). The land-based belt aims to connect Central Asia, the Middle East, West Asia, and parts of Europe, whereas the maritime route plans to connect Southeast Asia, South Asia, the Persian Gulf, the Red Sea, and the Indian Ocean coast. The Chinese government had allocated \$40bn for the new Silk Road plan. The major objectives of the new Silk Road plan include: (i) to boost in infrastructure construction projects, which would benefit railway construction, construction materials, and other transport sectors; (ii) to enhance inter-trade with China; and (iii) to promote all other kinds of trade including utilities, financial cooperation, and environmental issues (Lau et al, 2014).

Regional or pan-Asia projects may face challenges in terms of technical, legal, institutional, standard and regulatory obstacles. Countries involved in a regional projects need to agree on harmonized standards and technical specification for design, construction, operation and maintenance of the infrastructure asset among others. This calls for a proper institutional architecture for close cooperation, collaboration, partnership among participating countries

These pan-Asian ambitious initiatives will require strong collaboration, coordination and partnership among, national, regional and international institutes involved in infrastructure development, the governments and private sectors as well as other stakeholders. In addition to hard infrastructure, developing soft infrastructure, particularly cross-border issues is crucial. This paper will propose a new institutional architecture including a pan-Asian coordination framework to design, develop, finance and implement such cross-border connectivity projects.

\section{3, Major Challenges and Prospects of Infrastructure Connectivity}

There are many challenges facing increasing regional integration through regional connectivity in Asia. Among these is the challenge of building regional infrastructure that will support the continuing growth and development of Asian economies by both linking them together, particularly with large markets like China, Japan, Korea and India, and linking Asia with the rest of the world. At the same time, landlocked, and small countries and need to be connected to seaports, large markets and business centres as well as archipelagos. Achieving this goal will require the proper coordination and integration of existing and new national, subregional, and regional infrastructure programs and institutions. 


\subsection{Infrastructure for Basic Needs}

One of the major challenges in the coming decades will be how connectivity can address the pressing basic human needs (or basic services) of over two billion people for road and rail transportation, clean water, sewage treatment, electricity, health facilities, communications, etc. Nearly two-thirds of the world's poor live in developing Asia, with over 620 million people in the region living on US\$1 or less a day and about 1.9 billion people living on less than US\$2 a day (ADB 2007). Regional integration through greater infrastructure connectivity would allow Asian economies to share scarce resources, such as energy and water, to meet these basic needs among energy and water surplus and deficit countries.

Regional and International institutions involved in infrastructure development need to provide concessional funding for development of basic utilities the construction of which do not provide good economic rate of return. The private sectors are not usually interested in participating in the development of basic services. These institutions can facilitate the participation of private sector in a PPP model through co-financing and providing guarantees against various risks that cannot be managed by the private sectors.

\subsection{Infrastructure for Inclusive Growth}

Achieving inclusive growth through connectivity is another major challenge. Regions without proper connectivity cannot reap benefits from economic and trade growth. Lack of connection can bring desperation and conflict. Rural populations, landlocked or small or less developed countries, villages in mountainous and remote areas, islands or archipelagos, are often left behind due to lack of physical connectivity. Such regions may have special demands not faced by other regions, such as port and communications facilities for islands, for example. Appropriate regional infrastructure can benefit such special groups by connecting them to the centres of business activities.

Asian infrastructure institutions can assist governments to design appropriate infrastructure projects in a cost-effective manner to reach these regions or communities.

\subsection{Development of Effective "Soft Infrastructure"}

In general, financing "hard infrastructure" remains the main topic for discussion concerning the infrastructure development in Asia. However, "soft infrastructure" is essential for "hard infrastructure" to work effectively. Soft infrastructure includes appropriate policies, reforms, regulations, practices, systems and procedures; knowledge, know-how, technical capacity and institutions for effective infrastructure connectivity and for enabling inclusive and sustainable growth. In order to create an effective infrastructure network, countries need to

(i) Strengthen existing legal and regulatory frameworks and create new laws and regulation to ensure inclusive, sustainable, adequate, affordable, safe, and accessible infrastructure networks;

(ii) Establish independent infrastructure regulatory bodies for effective regulation;

(iii) Harmonize and standardize regulatory and legal frameworks and policies as well as practices, systems and procedures (e.g., customs practices) across border for efficient operation of cross-border or regional projects;

(iv) strengthen capacity of developing countries, particularly in designing and implementing PPP projects

(v) Create of an enabling environment for the private sector participation through PPP mechanisms

(vi) Ensure effective coordination, cooperation and collaboration, among various agencies and stakeholders

(vii) Identification and prioritization of projects at the national, sub-regional and regional levels; 
(viii) Manage social safeguards and environmental issues;

(ix) promote good governance for cost-effective and quality infrastructure development; and

(x) Develop innovating mechanisms and instruments for cost-effective infrastructure financing.

New and existing bilateral, regional and international institutions involved in infrastructure development have to play a major role to address the above areas in order achieve a seamless connectivity across many heterogeneous and diverse Asian countries and beyond. There is also a need for proper coordination, collaboration and partnership among all major stakeholders including the aforementioned institutions.

\subsection{Cost-effective, Innovative and Sustainable Infrastructure}

Cost-effective Infrastructure technologies in the areas of transport, energy and telecommunications (such as high speed trains, electric vehicles; solar, wind, nuclear and other renewable and clean energy sources and energy efficiency) can play an important role in building modern and sustainable infrastructure in developing Asia. However, these technologies are usually owned by firms of developed countries. Even though the perception of these technologies is very high in terms of quality and reliability, but the cost and maintenance expenses may be too expensive for developing Asian counties.

In recent years, the firms have been able to develop several innovative infrastructure technologies (such as high speed railways and electric vehicles) at much lower price than those developed by advance economies. Emerging developing countries such as China, India and major ASEAN economies together with advanced economies of Asia (such as Japan, Korea and Singapore) should collaborate to develop cost-effective innovative technologies (Aneja, 2015).

The major high-speed railway firms of China have been discussing with 30 countries regarding the development of rapid rail system. They are expected to achieve around 30\% market share of the world market in rapid railways by 2020 and $50 \%$ share by 2025 . The Chinese firms are able to produce good quality high-speed rails at a lower cost. The cost of developing high-speed trains by Chinese firms is estimated to be US $\$ 17$ million per $\mathrm{km}$ compared to the European firms' cost of $\$ 25-\$ 39$ per km (Aneja, 2015).

Encouraged by the governments, the companies of developed countries should be willing to provide innovative technology for environmentally sustainable infrastructure development in a cost-effective manner with a long-term profitability of the investment which will be a winwin situation for both developed and developing countries. At the same time, they should make efforts to improve the cost performance and suitability of their products in local conditions through joint research and other cooperation with local research institutions and laboratories in developing economies.

\subsection{Sustainable and Green Infrastructure}

Another major challenge is dealing with the negative externalities of infrastructure development, including the social and environmental consequences; and asymmetric distribution of cost and benefits to participating countries. Finding "win-win" solutions for all related parties or stakeholders, managing Asia's diversity, and avoiding or mitigating costs from negative externalities would allow the benefits of infrastructure development to be 
widely shared and are essential measures to create and sustain effective regional integration. Asia needs to create a green connectivity with minimal adverse impact on environment and climate change. The sustainable infrastructure projects need to be designed. Appropriate cost and benefit analysis of the projects needs to be performed not only in the context of the present generation but also for the future generation.

\subsection{Localization of Infrastructure Development}

Infrastructure development in developing countries based on foreign technology (from advanced economies) may not be cost-effective and sustainable in long-run. Developing countries with the assistance of regional and international institutions should ensure appropriate localized designs and technology for the infrastructure projects so that they meet the local needs and adjust to local conditions- social, economic and political customs. In addition, the maintenance of the infrastructure asset should be cost-effective and undertaken by domestic companies utilizing domestic resources. In many cases, the cost of maintenance become very high as the materials and manpower needed for maintenance are imported from advanced economies.

\subsection{Identification and Preparation of Bankable Projects}

The lack of bankable and commercially viable infrastructure projects, particularly crosscountry or regional projects is a very serious challenge. Infrastructure projects are complex and usually take a long time and it is often difficult to predict the return on investment.

There is an urgent need to design and develop bankable infrastructure projects with proper designs and using appropriate models such as various PPP models, and appropriate instruments (such as concessional financing for less developed countries) and other innovative approaches. Identification, prioritization and preparation of viable projects are often difficult and complex. There is a need to exhibit that cross-country projects can provide more benefits compared to national projects to attract developing countries to join the endeavor. Existing multilateral development banks (MDBs) like Asian Development Bank (ADB) and World Bank (WB), new MDBs such as Asian Infrastructure investment Bank (AIIB) and New Development Bank-BRICS (NDB); bilateral development banks or agencies ( such as the Japan Bank for International Cooperation (JBIC) and the Japan International Cooperation Agency (JICA) as well as the Export-Import Bank of China (CHEXIM), and Korea Export-Import Bank (KEXIM), investment banks, regional cooperation institutions and special national institutions need to enhance their roles in identifying, designing and preparing bankable projects.

\subsection{Financing Vast Infrastructure Needs}

The most important challenge, however, is to find ways to finance Asia's huge infrastructure investment needs. This will be discussed in the section 3 . 


\section{Financing Asia's Infrastructure Needs}

\subsection{Massive Infrastructure Financing Needs}

According to a recent Citi GPS report on "Infrastructure for Growth: The Dawn of a New Multi-Trillion Dollar Asset Class, the need for infrastructure financing globally is estimated to be $\$ 59$ trillion during the next 15 years, which will be a large opportunity for private sector investment (Citi GPS, 2016).

Asia accounts for a major portion of the global infrastructure financing needs. According Bhattacharyay (2012a), during 2010-2020, the financing needs of developing countries (32 major developing economies of Asia) in Asia is US\$777 billion per year for national (US\$748 billion) and regional (US\$29 billion) infrastructure to meet growing demand.

During 11 years period of 2010-2020, Asia needs a massive US \$ 8.22 trillion (in 2008 prices) with an average of US $\$ 747.5$ billion per year in national infrastructure in energy, transport, telecommunications, and water and sanitation to meet current and future demand. Of which $68 \%$ is for new capacity investment and $32 \%$ is for maintenance of existing assists. About $49 \%$ of the funding is needed in the energy sector, $35 \%$ for transport infrastructure, $13 \%$ for ITC, and 3\% for the water and sanitation sectors. This infrastructure needs account for around $6.5 \%$ of Asia's annual regional GDP and represent spending that exceeds the available resources of many Asian countries (Bhattacharyay, 2012a).

Furthermore, for the identified 1202 regional or cross-border projects, the total investments needed to meet demand is US\$320 billion - an average infrastructure investment need of about US\$29 billion per year for the period 2010-2020 (Bhattacharyay, 2012a).

According to a recent study by ADB (2017) on "Meeting Asia's Infrastructure Needs", the above 32 major developing countries of Asia needs \$ 17,426 billion (in 2008 prices) during a 15 years period of 2016-2030. The average per year need in national infrastructure is $\$ 1162$ billion - around 55\% higher than the Bhattacharyay(2010a) estimates. As this study covers 10 more years, namely 2021-30 which is expected to witness higher GDP growth, this estimates show a higher yearly infrastructure needs.

Table 1 presents a comparative picture of the above 2 estimates. This analysis reconfirms the massive infrastructure needs for Asia.

Table 1. Infrastructure Needs for Asia: A Comparison for 2010-20 and 2016-30

\begin{tabular}{|l|c|c|}
\hline \multicolumn{1}{|c|}{ Item } & $\begin{array}{c}\text { Bhattacharyay } \\
(2010 \mathrm{a}) \\
(\$ \text { billion in } \\
2008 \text { prices })\end{array}$ & $\begin{array}{c}\text { ADB (2017) } \\
\text { (\$ billion in } \\
2008 \text { prices })\end{array}$ \\
\hline Time Period & $2010-2020$ & $2016-2030$ \\
\hline $\begin{array}{l}\text { Total National } \\
\text { Infrastructure } \\
\text { Needs }\end{array}$ & 8,223 & 17,426 \\
\hline $\begin{array}{l}\text { Per Year National } \\
\text { Infrastructure } \\
\text { Needs }\end{array}$ & 748 & 1162 \\
\hline
\end{tabular}




\begin{tabular}{|l|c|c|}
\hline $\begin{array}{l}\text { Infrastructure } \\
\text { Needs for } \\
\text { Regional Projects }\end{array}$ & 390 & Not Available \\
\hline $\begin{array}{l}\text { Per Year } \\
\text { Infrastructure }\end{array}$ & 29 & Not Available \\
$\begin{array}{l}\text { Needs for } \\
\text { Regional Projects }\end{array}$ & & \\
\hline
\end{tabular}

Source: Bhattacharyay(2010a) and ADB(2017)

Note: Asia means 32 major developing countries in Asia

\subsection{Meeting the Vast Infrastructure Financing Gap}

Multilateral Development Banks (MDBs) have been playing an important role in filing the huge infrastructure financing gaps. However, their resources are limited. Even though the annual resource commitment from MDBs increased to USD 45 billion to more than USD 100 billion over a 10 year period, but it is not adequate to fill in the large gap ${ }^{2}$.

Many Asian countries do not have adequate fiscal space for financing this huge infrastructure investment. The private sector is concerned about the risks associated with long-term infrastructure financing. As there is a huge shortfall for national infrastructure financing, many less developed Asian countries may not be a position to meet the financing gap unless concessional or grant multilateral or bilateral funds or private sector funds are available.

At present, the international and regional financial markets are witnessing a turbulent and volatile period. The shrinking of international and regional financial markets means a corresponding decline in infrastructure and trade financing. A major priority for developing Asian countries is to find ways and means to mobilize its huge savings to fund its infrastructure development. This is of particular concern in rapidly urbanizing areas especially for transport, power, water and sanitation.

Furthermore, existing financing mechanism and instruments as well as institutions in Asia are inadequate in meeting the challenges of the magnitude and type of infrastructure financing needs. Banking sector is still the major source of infrastructure financing in Asia. Furthermore, private international capital flows tend volatile and are not adequate in volume and maturity to sustainable financing of infrastructure projects, which typically requires longterm financing.

In our opinion, it is not possible to find a single path to mobilizing sufficient funding for infrastructure in Asia. The financing requirements are too large, widespread, and diverse and would require multiple sources and mechanisms of funding. Various types of financing are appropriate for infrastructure projects belonging to various sectors and social, legal, or institutional settings. The new infrastructure financing mechanisms, instruments and institutions are required. The ability of existing institutions such as Multilateral Development Banks( MDBs) and bilateral development banks and other agencies are limited compared to the vast investment needs. However, mere establishment of new infrastructure financing institutions will not be sufficient to meet the large infrastructure gap. The existing and new institutions need to develop innovative financing mechanisms and instruments to utilize

\footnotetext{
${ }^{2}$ NDB Website, http://ndb.int/about-us.php
} 
Asian (at national, subreginal and regional levels) and international savings for its infrastructure development.

Bhattacharyay (2012b) proposed (i) financial instruments or infrastructure bonds based on multi-currency units including major Asian Currency Units as well as major currencies of major advanced economies such as US and Europe; (ii) guaranteed and linked bonds (iii) Islamic financial instruments like Sukuk, (iv) local currency bonds; and (v) subregional funds. I think the newly established Asia Infrastructure Investment Bank with several Islamic Gulf countries as a member can play an important role in developing the aforementioned innovative financial instruments.

\section{Role of International, Regional and Subregional Institutions in Effective Infrastructure Development}

The development and expansion of regional infrastructure networks depend on clear policies and effective regulatory arrangements (ADB, JBIC, and World Bank, 2005). Although governments are the key players in formulating infrastructure-related policies, rules and regulations, institutional arrangements, even if they are informal, provide the required coordination and related support on developing national and cross-border infrastructure networks (Schiavo-Campo and Sundaram, 2000).

The history, role, and effectiveness of regional institutions in Asia, Europe, and Latin America have been discussed by several authors. Most of them focused on trade and investment, including the need for soft infrastructure. For example, Komori (2007), Poole (2008), Jazic (2005), Cockerham (2009), and Aslan and Aslan (2006) discussed Asia-Pacific institutions such as ASEAN, Asia-Pacific Economic Cooperation (APEC), and Central Asia Regional Economic Cooperation (CAREC). On the other hand, Gomez-Mera (2008) discussed regional institutions and implementation of trade blocks, while Shimizu (2007) compared regional approaches in Europe and Asia. Nabers (2008) compared institution building in Asia and Europe (Bhattacharyay, 2010).

In terms of hard infrastructure development, ADB is the major multilateral financial institution supporting Asian economies in pursuing national, subregional, and regional infrastructure projects for enhancing regional integration, where the United Nations Economic and Social Commission for Asia and the Pacific (UNESCAP) proposed and supported the pan-Asian projects like the Asian Highway and the Trans-Asian Railway UNESCAP, 2010).

\subsection{Sub-regional Infrastructure Initiatives/Programs}

In view of the large diversities in Asian economies, the sub-regional and regional infrastructure development is being undertaken through many overlapping subregional institutions with members varying from 3 to 15 countries. These institutions are operating at varying speeds, addressing different degrees of infrastructure issues with a range of objectives. Furthermore, most of these institutions seem to be less effective, informal, and lacking a clear and binding system of rules and policies. To develop a seamless Asian connectivity, there is an urgent need for an effective, formal, and rules-based institutional framework (Bhattacharyay, 2010).

Sub-regional infrastructure connectivity in Asia so far have been planned under twelve major subregional initiatives including GMS, ASEAN, CAREC, South Asian Association for Regional Cooperation (SAARC), South Asia Subregional Economic Cooperation (SASEC), Pacific Island Forum (PIF), Indonesia-Malaysia-Thailand Growth Triangle (IMT-GT), Brunei Darussalam Indonesia Malaysia Philippines - East Asian Growth Area (BIMP-EGA), Bay of 
Bengal Initiative for Multi-Sectoral Technical and Economic Cooperation (BIMSTEC, Subregional Economic Cooperation in South and Central Asia (SECSCA) and Greater Tumen Initiative (GTI) IN Northeast Asia. Pan-Asian connectivity initiatives such as Asian Highways and Trans-Asian Railway (TAR) have been implemented as part of subregional and national programs. Of the subregional initiatives, Greater Mekong Subregion (GMS) has made the most significant progress in strengthening connectivity, mainly through crossborder transport and economic corridors.

\subsection{Role of Existing MDBs}

During last 50 years, ADB has an impressive track record as a reliable funder of a large and board varieties of national regional infrastructure projects. It has provided traditional financing and other types of assistance at competitive rates in the form of loan, equity financing, various risk guarantees, syndication arrangements and technical assistance as well as local currency financing in recent years. With a large capital of $\$ 165$ billion and strong technical expertise, ADB is capable of facilitating the mobilization of additional funds for infrastructure investment. ADB can play an important role in developing both "hard and soft infrastructure" for enhancing Asian connectivity.

World Bank (WB), an international development bank has also invested significantly in Asia's infrastructure development, but it has been primarily invested in national infrastructure projects. The European Investment Bank (EIB) has a small infrastructure operation in Asia and since 1993 has been undertaking projects in countries such as Bangladesh, , India, Indonesia, Laos PDR, Maldives, Pakistan, Philippines, Thailand, Sri Lanka, and Viet Nam (EIB 2008).

\subsection{Role of New MDBs}

There is enough opportunity for new institutions in the infrastructure financing as the financing requirement in Asia is very large and designing bankable projects is a great challenge as there are several risks associated with large and long-term infrastructure financing projects. However, mere

Bhattacharyay (2012b) proposed an Infrastructure Financing Bank (AIFB) or Asia Infrastructure Financing Fund. The AIFB will be a new specialized infrastructure investment bank.

New regional and international institutions like "Asia Infrastructure Investment Bank" (AIIB) and "New Development Bank" (NDB) or "BRICS Bank" have been established in 2015 to fill in the infrastructure financing gap. The AIIB and NDB aim to provide financing for long term sustainable projects in energy, power, rural infrastructure and agriculture, transportation and telecommunications, water supply and sanitation, environmental protection, urban development and logistics in developing economies.

\subsubsection{Asia Infrastructure Investment Bank}

The mission of AllB's is to strengthen economic and social development in Asia by financing in high quality, financially viable and environmentally friendly infrastructure projects ${ }^{3}$.

AllB with a capital of $\$ 100$ billion and 70 member countries and developing countries as major shareholders will focus on developing infrastructure and other productive sectors in Asia. Table 2 provides focus areas, institutional goals, thematic priorities and major projects of AllB and NDB. 
However, there should be some distinct complimentarily in the role of these new institutions as well as an environment of a healthy completions among regional financing institutions and bilateral development banks or agencies for effective infrastructure development.

If regional integration through increased connectivity is to succeed, it is essential to build or strengthen national, subregional, regional and international institutions involved in infrastructure development within an effective institutional framework.

Table 2: AllB Framework (Focus Areas, Institutional Goals and Thematic Priorities)

\begin{tabular}{|c|c|c|c|}
\hline Focus Areas & Institutional Goals & Thematic Priorities & $\begin{array}{c}\text { Member } \\
\text { Countries/Approved } \\
\text { Projects }{ }^{4}\end{array}$ \\
\hline $\begin{array}{l}\text { 1. Rural } \\
\text { Infrastructure and } \\
\text { Agricultural } \\
\text { Development } \\
\text { 2. Energy and Power } \\
\text { 3. Environmental } \\
\text { Protection }\end{array}$ & $\begin{array}{l}\text { 1. Sharpening the } \\
\text { Bank's Strategic } \\
\text { Focus and Shaping } \\
\text { its Corporate Brand } \\
\text { 2. Scaling-Up } \\
\text { Support to Clients } \\
\text { and Refining the } \\
\text { Programming } \\
\text { Approach } \\
\text { 3. Bolstering } \\
\text { Financial } \\
\text { Sustainability and } \\
\text { Paving the Way for } \\
\text { Market Access } \\
\text { 4.Continuing } \\
\text { Institution Building }\end{array}$ & $\begin{array}{l}\text { 1. Sustainable } \\
\text { Infrastructure } \\
\text { Promoting green } \\
\text { infrastructure and } \\
\text { supporting countries } \\
\text { to meet their } \\
\text { environmental and } \\
\text { development goals. } \\
\text { 2. Cross-country } \\
\text { Connectivity } \\
\text { Prioritizing cross- } \\
\text { border infrastructure, } \\
\text { ranging from roads } \\
\text { and rail, to ports, } \\
\text { energy pipelines and } \\
\text { telecoms across } \\
\text { Central Asia, and the } \\
\text { maritime routes in } \\
\text { South East and } \\
\text { South Asia, and the } \\
\text { Middle East, and } \\
\text { beyond. } \\
\text { 3. Private Capital } \\
\text { Mobilization } \\
\text { Devising innovative } \\
\text { solutions that } \\
\text { catalyze private } \\
\text { capital, in } \\
\text { partnership with } \\
\text { other MDBs, } \\
\text { governments, private } \\
\text { financiers and other } \\
\text { partners }\end{array}$ & $\begin{array}{l}\text { 1. Azerbaijan: Trans } \\
\text { Anatolian Natural } \\
\text { Gas Pipeline Project } \\
\text { (TANAP) (co- } \\
\text { financed with the } \\
\text { WB, EBRD and ECB) } \\
\text { Amount: US \$ } 600.00 \\
\text { million } \\
\text { 2. Oman: Duqm Port } \\
\text { Commercial Terminal } \\
\text { and Operational } \\
\text { Zone Development } \\
\text { Project } \\
\text { Amount: US } \$ 265 \\
\text { million } \\
\text { 3. Oman: Railway } \\
\text { System Preparation } \\
\text { Project } \\
\text { Amount: US\$20 } \\
\text { million } \\
\text { 4. Myanmar: } \\
\text { Myingyan Power } \\
\text { Plant Project (co- } \\
\text { financed by IF and } \\
\text { ADB) } \\
\text { Amount: US } \$ 20 \\
\text { million } \\
\text { 5. Pakistan: Tarbela } \\
5 \text { Hydropower } \\
\text { Extension Project } \\
\text { (co-financed by WB) }\end{array}$ \\
\hline
\end{tabular}

\footnotetext{
${ }^{4}$ AllB Website, https://www.aiib.org/en/projects/approved/index.html
} 


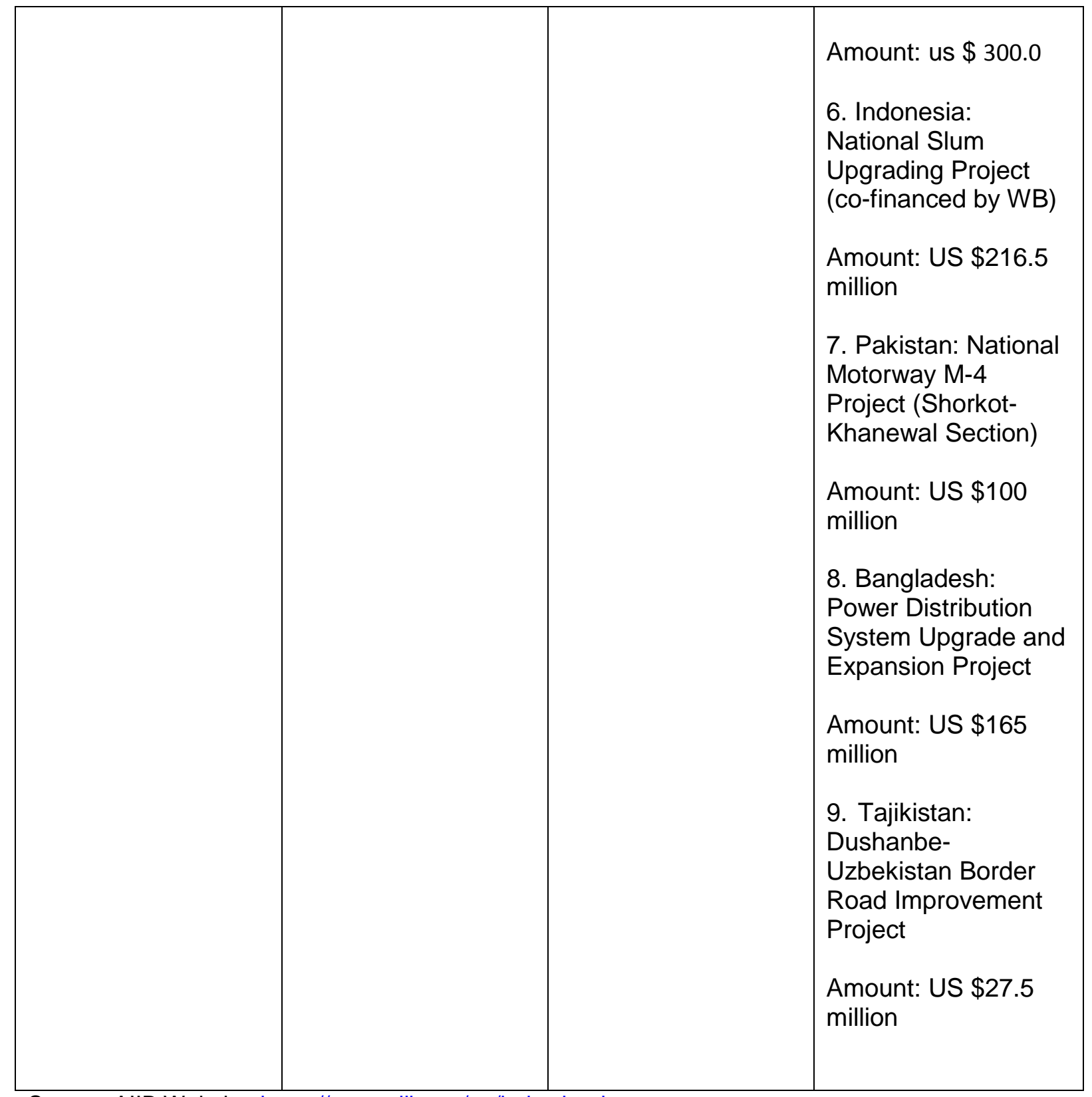

Source: AllB Website, https://www.aiib.org/en/index.html

\subsubsection{New Development Bank}

The New Development Bank- NDB (formerly known as BRICS bank) was established by Brazil, Russia, India, China and South Africa with a capital of $\$ 100$ billion. The major objective of NDB is to finance infrastructure projects in the developing economies (including Asia) and promote sustainable development. NDB aims to mobilize financial resources for infrastructure and sustainable development projects in BRICS and developing economies which will complement the activities of multilateral and regional financial institutions for global growth and development. It plans to develop partnerships with multilateral and national development banks for utilize the expertise and knowledge of established 
development institutions, which will strengthen its capacity to design, assess and implement projects ${ }^{5}$.

In terms of projects, NDB so far approved fours loans worth some $\$ 811$ million in Brazil $(\$ 300)$, China (\$81), South Africa (\$180 million) and India (\$250 million). These projects focus on sustainable infrastructure development, namely renewal energy development ${ }^{6}$.

Table 3 provides vision, key goals, and major approved and pipeline projects of AllB and NDB.

Table 3: NDB Framework (Goals and Projects)

\begin{tabular}{|c|c|}
\hline Vision/Key Goals & Member Countries and Key Projects (2016) \\
\hline $\begin{array}{l}\text { Vision: } \\
\text { to support and foster infrastructure } \\
\text { and sustainable development } \\
\text { initiatives in emerging economies } \\
\text { Major Goals: } \\
\text { 1. Infrastructure } \\
\text { Infrastructure development in } \\
\text { emerging economies as a priority } \\
\text { and aims to identify and bridge } \\
\text { the gaps between existing } \\
\text { "infrastructure needs" and } \\
\text { "funding" opportunities. It also } \\
\text { aims to be a partner in bringing } \\
\text { about truly holistic development. } \\
\text { 2. Sustainable Development } \\
\text { Sustainable development by } \\
\text { focusing on initiatives that drive } \\
\text { growth and employment while } \\
\text { ensuring environmental } \\
\text { protection. }\end{array}$ & $\begin{array}{l}\text { • Brazil } \\
\text { Borrower: BNDES } \\
\text { End User: Sub-projects } \\
\text { Target Sector: Renewable Energy (wind, solar,etc.) } \\
\text { • Russia } \\
\text { Borrower: EDB/IIB } \\
\text { End User: Nord Hydro Bely-Porog } \\
\text { Target Sector: Renewable energy (hydro-power); } \\
\text { Green energy } \\
\text { • India } \\
\text { 1. Borrower: Canara Bank } \\
\text { Gurantor: Government of India } \\
\text { End User: Sub-projects } \\
\text { Target Sector: Renewable Energy (wind, solar, etc.) } \\
\text { 2. Borrower: Government of India } \\
\text { End User: Government of Madhya Pradesh } \\
\text { Target Sector: Upgrading major district roads } \\
\text { • China } \\
\text { 1. Shanghai Lingang Distributed Solar Power Project } \\
\text { Borrower: PRC Government } \\
\text { End User: Shanghai Lingang Hongbo New Energy } \\
\text { Development Co. Ltd. } \\
\text { Target: Renewable Energy (Solar roof top) } \\
\text { 2. Fujian Putian Pinghai Bay Offshore Wind Power } \\
\text { Project } \\
\text { Borrower: PRC Government } \\
\text { End User: Fujian Investment and Development Group } \\
\text { Target Sector: Wind Energy }\end{array}$ \\
\hline
\end{tabular}

\footnotetext{
${ }^{5}$ NDB Website, http://ndb.int/pdf/NDB-Fact-Sheet.pdf

${ }^{6}$ BRICS bank approves first loans, $\$ 811 \mathrm{mn}$ investment in renewable energy projects, RT, 16 April 2016 https://www.rt.com/business/339797-ndb-first-project-loans/
} 


\begin{tabular}{|l|l|}
\hline & \multicolumn{1}{|c|}{ South Africa } \\
& Borrower: ESKOM \\
& Guarantor: Government of RSA (Republic of South \\
& Africa) \\
& End User: ESKOM \\
& Target Sector: Renewable Energy (Transmission) \\
\hline
\end{tabular}

Source: NDB Website, http://ndb.int/about-us.php

New MDBs can play an important role if they can complement the existing MDBs investing Asia's infrastructure and specialize in certain areas such as

(i) financing regional or cross-border infrastructure projects through designing bankable projects and lending instruments;

(ii) developing appropriate financial instruments, such as multicurrency infrastructure financing instruments (e.g. multi-currency infrastructure bonds); and

(iii) Islamic financial instruments among others.

\subsection{Coordination and Cooperation Among MDBs}

Existing and new MDBs can compete (in a healthy manner), collaborate and cooperate to:

(i) effectively intermediate the larger use of financial assets for infrastructure development;

(ii) provide cost-effective and timely infrastructure loans and knowledge, particularly in energy, and transport with simple, user-friendly and smooth practices, systems and procedures; and collaborate with the banking and financial sector in cofinancing and guaranteeing private investment;

(iii) Prepare, develop, evaluate, prioritize regional infrastructure projects and negotiate with governments for the agreement to implement them;

(iv) Design, develop and implement effective instruments to direct Asian and international savings for its infrastructure development and develop expertise in regional infrastructure bond financing and other innovative financial instruments, such as:

- Lending instruments for regional or cross-border projects;

- Multicurrency financial instruments or bonds based on Asian Currency Units;

- Guaranteed and linked bonds;

- Islamic financial instruments like bonds and Sukuk;

- Local currency bonds;

- Securitized infrastructure loans; and

- Sub-regional funds like ASEAN Infrastructure Fund;

(v) Guarantee instruments against major risks (e.g., operational, financial, country, disasters and political risk) and

(vi) Financing instruments for sustainable and inclusive regional or cross-border projects.

Bhattacharyay (2012b) proposed a pioneering financial instrument, namely, Multicurrency Infrastructure Bonds (MIBs) denominated in Asian Infrastructure Currency Units (AICU) which are regional accounting units (RAUs) to serve as a key financing mechanism for infrastructure investment needs in Asia. This financial instrument can reduce currency and maturity risks. AICU as an accounting unit can be used in official transactions and for public and private financial instruments with respect to infrastructure and other types of financing. $\mathrm{He}$ found that the advantages of the AICU to promote integrated financial market 
development are sufficient to justify its creation, and thus he does not propose an additional use as a parallel currency, nor as a precursor to an Asian currency. The existing and new regional MBDs such as ADB and AllB in Asia together with Asian governments could be involved in developing this financial instrument.

AlIB with wealthy Islamic Gulf countries as members has an opportunity to specialize in developing appropriate Islamic financial instruments for infrastructure financing and mmulticurrency financial instruments or bonds based on Asian Currency Units to minimize risk.

The regional and international MDBs and bilateral aid agencies should assist developing countries of Asia in creating effective and enabling "soft infrastructure" through capacity building and effective coordination and cooperation among them.

There is lack of bankable and commercially viable projects in developing economies of Asia, particularly in the utility and social infrastructure sector which does not provide adequate economic return but meets social needs of the citizens. Existing MDBs like ADB and WB, new MDBs such AIIB and NDB, bilateral and special national institutions need to enhance their role in identifying and designing bankable and commercially viable national and regional projects in these sectors which may need concessional financing and undertake capacity building for low-income developing countries.

At present, MDBs like WB and ADB finance projects at the country level. For enhancing connectivity, Asia needs to develop and implement suitable financial products for regional infrastructure projects involving several countries within a sub-region. In order to implement connecting cross-border or regional infrastructure projects, appropriate and innovative design, financing instruments and mechanisms are required.

\section{Structure and Characteristics of Bilateral, Regional and International Institutions}

The institutions involved with infrastructure projects in Asia vary widely in terms of their key characteristics including: major sectoral focus; region of operation; major functions; form of the institution (e.g. formal or informal); highest level of participation from governments of participating countries; and modalities (ADB/ADBI 2009). The key features/ characteristics of Asian subregional institutions and programs can be summarized as follows:

1. Most institutions are involved with both hard and soft infrastructure, including such areas as economic integration, trade facilitation, and transport and energy infrastructure.

2. With the exception of ASEAN and SAARC, all institutions are informal in nature without any legally binding or enforcement capacity and even the formal ASEAN follows noninterference, sovereignty, incrementalism, and consensual decision-making.

3. Most institutions have multiple objectives such as integration, trade, infrastructure, and socio-economic.

4. A dedicated institution for regional/cross-border infrastructure only is lacking. Now AllB fills in this gap if it focuses on regional infrastrucutre.

5. Most institutions have advisory and regulatory modalities without any financing modality.

6. Most institutions enjoy high level (such as summit or ministerial-level) participation from governments (Bhattacharyay, 2010). 
As such subregional cooperation programs/institutions typically lack financing facilities/capacities, they would need to establish strong cooperation and coordination arrangement with major multilateral financing institutions such as ADB, WB, AllB, and NDB; and major bilateral financing institutions like the Japan Bank for International Cooperation (JBIC) and the Japan International Cooperation Agency (JICA) as well as the Export-Import Bank of China (CHEXIM), and Korea Export-Import Bank (KEXIM).

In order to accommodate the diversities in Asian economies, Asia's regional infrastructure development has been undertaken through several overlapping subregional programs/initiatives with a range of objectives. These trends may reflect socio-political situations in Asia where some subregions are more eager to engage in infrastructure cooperation than others. To achieve the pan-Asian connectivity, existing subregional programs, would need to be coordinated and integrated to accommodate varying needs, speeds, and interests in subregional and regional integration. These overlapping subregional programs could be the fundamental building blocks for enhancing connectivity across subregions such as East Asia, Southeast Asia, Central Asia, and South Asia, which could in turn develop connectivity across the Asian region as a whole by connecting the above subregions (Bhattacharyay, 2010).

Strong and effective national and regional institutions with effective governance and accountability structures are essential for the successful development of an effective panAsian connectivity. The roles of these institutions would include the harmonization and standardization of rules, regulations, policies, processes, practices, systems and procedures for the free movements of goods and services across borders. Such institutions would also work to help create enabling environments for private sector participation through Public Private Partnership (PPP) mechanisms.

A regional system will only be as successful as its weakest link, a concept known as the "network challenge". For a system to be "seamless", it must have common rules and regulations, which is only possible through stable and transparent frameworks and regulatory regimes. The degree of involvement of the private sector will depend on the clarity and transparency of rules and regulations. Therefore, regional institutions need to play an active role to establish common or harmonized rules and regulations.

Another institutional challenge is to coordinate regional infrastructure projects involving many stakeholders. These include harmonizing standards and regulations and equalizing interests, costs, and benefits, among others. A supranational coordinating body is needed, to demonstrate the political incentive to various stakeholders such as Asian governments and private sector entities joining the AICF. This body needs to ensure trust and confidence through transparent and accountable processes and good governance, and should be able to address the information asymmetry between the public and private sector and other stakeholders. The APEC business forum, which fulfils a similar role regarding trade and business facilitation, could be used as an example.

As a result of the global financial crisis and the global economic downturn, many Asian governments have insufficient resources for the required infrastructure investments. Furthermore, Asian and International financial markets are exhibiting highly turbulent and volatile environment dampening investors' confidence. Enabling environments for publicprivate partnerships and mechanisms to mobilize funds from regional capital markets for bankable regional projects need to be created. Many less developed Asian economies need to develop greater technical skills and capacities to be capable of designing and implementing regional projects. This calls for a dedicated institution for identifying and preparing bankable regional projects, mobilizing funds and facilitating their implementation. It also calls for assisting participating countries with capacity building, particularly in terms of human capital, to create appropriate soft infrastructure systems. 
Table 4 presents characteristics of major international, regional, subregional and bilateral Institutions and Programs Involved in Asian Infrastructure Development.

Table 4: Characteristics of Major International, Regional, Subregional and Bilateral Institutions and Programs Involved in Asian Infrastructure Development

\begin{tabular}{|c|c|c|c|}
\hline Name & $\begin{array}{l}\text { Year } \\
\text { Established }\end{array}$ & Members/ Participants & Objective in infrastructure Development \\
\hline UNESCAP & 1947 & 62 members & $\begin{array}{l}\text { Aims to integrate road, rail, sea, and air links } \\
\text { through improved logistics and intermodal } \\
\text { interfaces }\end{array}$ \\
\hline$\overline{\mathrm{AH}}$ & 1992 & $\begin{array}{l}32 \text { countries; } \\
28 \text { signed agreements } \\
23 \text { ratified agreements }\end{array}$ & $\begin{array}{l}\text { Aims to be a network of } 141,271 \mathrm{~km} \text { of } \\
\text { standardized highways }\end{array}$ \\
\hline TAR & 1992 & $\begin{array}{l}28 \text { countries; } \\
9 \text { ratified agreements }\end{array}$ & $\begin{array}{l}\text { Aims to span } 141,000 \mathrm{~km} \text { of railways across } \\
28 \text { countries }\end{array}$ \\
\hline WB & 1944 & 186 countries & $\begin{array}{l}\text { Primarily national Infrastructure development } \\
\text { operation in all Asian countries }\end{array}$ \\
\hline ADB & 1966 & 67 countries & $\begin{array}{l}\text { Aims for infrastructure connectivity through } \\
\text { regional cooperation }\end{array}$ \\
\hline $\mathrm{JBIC}^{\mathrm{JICA}}{ }^{\prime}$ & $\begin{array}{l}\text { JBIC - } \\
\text { 1961JICA- } 1974 \\
\text { Merged- } 2008 \\
\text { Demerged- } \\
2012\end{array}$ & Involved in 100 countries & $\begin{array}{l}\text { Infrastructure development for people's } \\
\text { empowerment operation in most Asian } \\
\text { countries }\end{array}$ \\
\hline EIB & 1958 & 142 countries & $\begin{array}{l}\text { The mandate focuses on private sector } \\
\text { development, infrastructure development, } \\
\text { security of energy supply and environmental } \\
\text { sustainability operation in } 11 \text { Asian countries. }\end{array}$ \\
\hline APEC & 1989 & 21 countries & $\begin{array}{l}\text { A forum to facilitate economic growth, } \\
\text { cooperation, trade and investment }\end{array}$ \\
\hline ASEAN & 1967 & 10 countries & $\begin{array}{l}\text { Seeks to promote greater cooperation and } \\
\text { coordination among nations and aims for the } \\
\text { integrated energy, transport, and } \\
\text { communication networks for regional trade } \\
\text { and investment. }\end{array}$ \\
\hline KEXIM & 1976 & & $\begin{array}{l}\text { provide loans, equity participations and/or } \\
\text { working capital to overseas investments } \\
\text { projects, and the development of overseas } \\
\text { natural resources and infrastructure projects. }\end{array}$ \\
\hline GMS & 1992 & 6 countries, ADB & $\begin{array}{l}\text { Main goal is to improve connectivity } n \text { the } \\
\text { subregion through improving transport, } \\
\text { energy and telecommunications links. }\end{array}$ \\
\hline MRC & & $\begin{array}{l}4 \text { countries } \\
\text { the Mekong River. }\end{array}$ & Covers only management and use of \\
\hline IMT-GT & 1993 & 3 countries & $\begin{array}{l}\text { Aims to expand opportunities for trade and } \\
\text { investment through improved infrastructure } \\
\text { and connectivity }\end{array}$ \\
\hline BIMP-EAGA & 1994 & 4 countries, $\mathrm{ADB}$ & $\begin{array}{l}\text { Seeks to expand opportunities for trade and } \\
\text { investment through infrastructure } \\
\text { development. }\end{array}$ \\
\hline CHEXIM & 1994 & & $\begin{array}{l}\text { Provide loans, equity participations and/or } \\
\text { working capital to offshore subsidiaries to } \\
\text { support resource security (energy production } \\
\text { and industrial use) and infrastructure projects } \\
\text { and Chinese Government concessional loan. }\end{array}$ \\
\hline
\end{tabular}

${ }^{7} \mathrm{JBIC}$ and JICA have been separated since 2012. 


\begin{tabular}{|c|c|c|c|}
\hline & & & \\
\hline BIMSTEC & 1997 & 7 countries & $\begin{array}{l}\text { Aims for economic integration through free } \\
\text { trade agreement and improving transport } \\
\text { infrastructure and logistics among its member } \\
\text { countries }\end{array}$ \\
\hline CAREC & 1997 & $\begin{array}{l}8 \text { countries, } 6 \text { multilateral } \\
\text { institutions, including ADB }\end{array}$ & $\begin{array}{l}\text { Aims for regional integration and trade, with } \\
\text { infrastructure (transport and energy) as one } \\
\text { of its major functions. Aims to enhance } \\
\text { energy security through regional energy } \\
\text { projects and develop transport corridors to } \\
\text { improve connections to regional and world } \\
\text { markets. }\end{array}$ \\
\hline SAARC & 1985 & 8 countries, 9 observers & $\begin{array}{l}\text { Main objective is economic integration though } \\
\text { free trade area. }\end{array}$ \\
\hline SASEC & 2001 & 4 countries, ADB & $\begin{array}{l}\text { Vision is to develop, utilize and optimize } \\
\text { power links }\end{array}$ \\
\hline SECSCA & 2003 & $\begin{array}{l}6 \text { countries, } 1 \text { observer, } \\
\text { ADB }\end{array}$ & $\begin{array}{l}\text { Aims to promote transport connectivity and } \\
\text { facilitate the movement of goods and people } \\
\text { across South and Central Asia. }\end{array}$ \\
\hline GTI & 1995 & 5 Countries, UNDP & $\begin{array}{l}\text { Promotes regional cooperation to ensure } \\
\text { energy security, improve basic infrastructure, } \\
\text { develop tourism, and promote international } \\
\text { environmental standards in Northeast Asia }\end{array}$ \\
\hline PIF & 1971 & $\begin{array}{l}16 \text { countries, } 4 \text { country } \\
\text { observers, ADB }\end{array}$ & $\begin{array}{l}\text { Aims to expand trade in goods and services } \\
\text { and enhance governance mechanisms and } \\
\text { strategies related to maritime and aviation } \\
\text { security }\end{array}$ \\
\hline \multicolumn{4}{|r|}{ 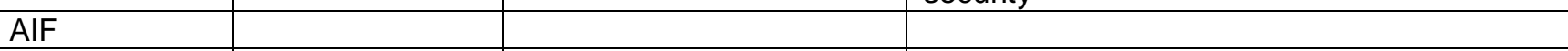 } \\
\hline AllB & 2015 & 57 countries & $\begin{array}{l}\text { To develop infrastructure and other } \\
\text { productive sectors in Asia, including energy } \\
\text { and power, transportation and } \\
\text { telecommunications, rural infrastructure and } \\
\text { agriculture development, water supply and } \\
\text { sanitation, environmental protection, urban } \\
\text { development and logistics }\end{array}$ \\
\hline NDB BRICS & 2015 & 4 countries & $\begin{array}{l}\text { Major focus is to lend for infrastructure } \\
\text { projects with authorized lending capacity of } \\
\text { up to } \$ 34 \text { billion annually }\end{array}$ \\
\hline
\end{tabular}

Sources: Author-adapted and revised from ADB/ADBI (2009), Bhattacharyay and De (2009a), and compilation from subregional programs and AIIB and NDB websites.

Through cost-benefit analysis, this institute needs to demonstrate the comparative advantage of regional projects vis-à-vis national projects. Less developed countries lacking strong debt repayment and technical capacities should be assisted through concessional or grant funds. Ensuring that regional infrastructure is environmentally friendly should be a guiding theme when developing project proposals. As environmentally friendly projects may in some cases be more expensive, they may need to be supplemented with concessional loans, grants, or other means such as clean development mechanism (CDM) certification and carbon credit trading, along with technical assistance from Multilateral Development Banks (MDBs) and other bodies.

\section{Toward a New Institutional Architecture for Asian Connectivity}

Market-led Asia's integration, its fragmented institutional arrangements and heterogeneity in the level of development among countries call for a pan-Asian approach with a new pan- 
Asian institutional framework integrating existing subregional/regional institutions and their initiatives.

An effective framework for the pan-Asian infrastructure connectivity needs:

- A common vision, strong leadership, and a shared commitment by Asian leaders;

- Strong institutional capacities at the national, subregional, and regional levels;

- Coherent infrastructure development at the national, subregional, and regional levels;

- Pan-Asian sectoral infrastructure strategies/plans to prioritize projects, investments and coordinate policies;

- Effective financing framework to help mobilize the region's vast savings; and

- Encouragement of public-private partnerships

For successful implementation of ongoing pan-Asian projects like "Asian Highway and Railway" project and of a new and ambitious pan-Asian project covering regions beyond Asia, namely "One Belt and One Road Project", Asia needs a new, formal and strong panAsian institutional Architecture. Figure 1 (see Appendix) presents the envisioned a new institutional architecture for enhancing Asian Connectivity.

Pan-Asian connectivity will be achieved in three steps:

(i) connecting interiors to economic/business centers and ports within countries;

(ii) connecting neighboring countries within subregions; and

(iii) connecting subregions to each other for pan-Asian connectivity.

There is a need to identify and prepare priority bankable or economically viable projects pipeline through a project development mechanism. A pan-Asian coordinating body such as "Asian Infrastructure Coordination (AICF)" should be established to help:

(i) coordinating and integrating existing overlapping national, subregional, regional and international infrastructure initiatives/programs and international/regional/ subregional/bilateral financial institutions toward building a seamless Asia;

(ii) developing explicit, treaty-based, legally binding rules and regulations; and

(iii) regulating with compliance monitored by a standing body or secretariat.

This public-private partnership facility will facilitate pan-Asian cooperation, coordination, and partnership among various stakeholders at the national, sub-regional, regional and international levels for identifying, prioritizing and preparing national/subregional/regional projects for Asian connectivity. Increased and strong coordination, collaboration and partnership among international/regional/bilateral infrastructure financing institutions are essential for a seamless Asian connectivity.

The major sources of financing will include:

(i) Multilateral Development Banks,

(ii) Asian (Regional)/ Subregional/Bilateral Infrastructure Funds/Programs,

(iii) National Governments,

(iv) National Infrastructure Banks/Funds/programs,

(v) Capital Markets, and

(vi) Private Sector. 
Figure 2 (see Appendix) exhibits the institutional framework of the AICF. The AICF Secretariat should be assisted by several technical expert committees, which would prepare a pan-Asian strategic plan for infrastructure connectivity as well as sectoral strategies and policies for regional infrastructure projects. With the assistance of subregional, regional and international institutions, the AICF will undertake the following activities:

(i) Identification, selection and prioritization of national/subregional/regional infrastructure projects;

(ii) Preparation of agreed list of priority national/subregional/regional projects; and

(iii) Monitoring the implementation of priority projects.

Figure 3 (see Appendix) presents the proposed organizational structure of the AICF Secretariat. The secretariat would support various sub-forums/facilities under the AICF:

(i) policy, legal, and regulation sub-forums for the formulation, standardization, and harmonization of legal and regulatory policies and for discussion of other key policy challenges;

(ii) key thematic and sectoral sub-forums such as energy, transport, ICT, and telecommunications, private sector and public private partnerships, financing, and logistics and trade facilitation;

(iii) gathering common or harmonized infrastructure statistics and information, and database management; and

(iv) capacity building and training, research, particularly cost-benefits and policy analysis.

The major conclusions include:

- As stated earlier that establishing new infrastructure financing institutions may not be sufficient in meeting vast infrastructure financing gap. There is a need to come up with innovative financing mechanism and financial instruments at the national, subregional, regional and international levels;

- Training, capacity building and research institutes and PPP centres should be established under the secretariat;

- A high-level national infrastructure committee chaired by the Prime Minster or President of the country needs to be established for effective cooperation, coordination, and partnership among various national agencies involved in infrastructure development.

- Following the recent example of Canada, a national infrastructure fund or bank needs to be established in Asian economies.

- The effective establishment and operation of the above new institutional architecture can contribute significantly toward the Asian seamless connectivity and beyond, particularly panAsian infrastructure projects, such as Asian highway and railway and One Belt and One Road Project.

\section{Bibliography}

Asian Development Bank (ADB), 2017, Meeting Asia's Infrastructure Needs, Asian Development Bank, Manila.

2007. ADB Annual Report 2007. Manila: Asian Development Bank.

ADB and ADB Institute. 2009. Infrastructure for a Seamless Asia. Tokyo: Asian Development Bank Institute and Asian Development Bank. 
Asian Development Bank, Japan Bank for International Cooperation, World Bank (ADBJBIC-WB). 2005. Connecting East Asia: A New Framework for Infrastructure. Washington D.C: World Bank.

Aneja, A., 2015, China pins faith on electric cars and high-speed trains to revive slowing economy, Hindu, 6 October, pp 15 accessed at:http://www.thehindu.com/business/chinapins-faith-on-electric-cars-and-highspeed-trains-to-revive-slowingeconomy/article7727206.ece

Aslan, K., and M. Aslan. 2006. Institutional Factors that Shape Regionalization in Central Asia. Paper presented at the Annual Meeting of the International Studies Association, Town \& Country Resort and Convention Center, San Diego, CA, USA, 22 March 2006. Accessed online: http://www.allacademic.com/meta/p100611_index.html.

Association of Southeast Asian Nations (ASEAN). 2008. ASEAN Economic Community Blueprint. Jakarta: ASEAN Available at: http://www.aseansec.org/5187-10.pdf.

Bhattacharyay B. N., 2010, Institutions for Asian Connectivity, Asian Development Bank Institute Working Paper Series No. 220, Tokyo

2012a, Estimating Demand for Infrastructure in Energy, Transport, Telecommunications, Water and Sanitation in Asia and the Pacific: 2010-2020,

in the book "Infrastructure for Asian Connectivity" (Edited by Bhattacharyay B. N. et. al.), Edward Elagar

2012b, Modes of Asian Financial Integration: Financing Infrastructure, page 349-401 in the book "Infrastructure for Asian Connectivity" (Edited by Bhattacharyay B. N. et. al.), Edward Elagar.

Bhattacharyay, B. N., and De., P. 2009. Restoring the Asian Silk Route: Towards the Vision of an Integrated Asia. ADBI Working Paper. Tokyo: Asian Development Bank Institute.

Citi GPS, 2016. New Citi Report: Infrastructure - the \$59-trillion opportunity to kickstart global growth, October 20, http://finance.yahoo.com/news/citi-report-infrastructure-59-trillion070000747.html

Cockerham, G. 2009. Regional Integration in Southeast Asia: Institutional Design and The ASEAN Way. Paper presented at the ISA's 50th Annual Convention, Exploring The Past Anticipating The Future, New York Marriott Marquis, New York City, NY, USA, 15 Feb 2009. Accessed online: http://www.allacademic.com/meta/p314277 index.html

Gomez-Mera, L. 2008. The Impact of Regional Institutions: An Empirical Study of Compliance and Implementation in Regional Trade Blocs. Paper presented at the ISA's 49th Annual Convention, Bridging Multiple Divides, San Francisco, CA, USA, 26 Mar 2008. Accessed online: http://www.allacademic.com/meta/p252505 index.html.

Jazic, Z. 2005. Regional Integration and Globalization European Union and Comparison with Asian Regional Institutions (ASEAN and APEC). Paper presented at the Annual Meeting of the International Studies Association, Hilton Hawaiian Village, Honolulu, HI, 05 March 2005. Accessed at: http://www.allacademic.com/meta/p70469 index.html

Kiernan, M., 2015, Silk Road Key to China's Next Move, 1 September, huffingtonpost.com http://www.huffingtonpost.com/matthew-j-kiernan/silk-road-key-to-chinas-

n_b_8068318.html?ir=India\&adsSiteOverride=in 
Krugman, P. 1991. Increasing Returns and Economic Geography. Journal of Political Economy 99(3): 483-499.

Komori, Y. 2007. Constructing Regional Institutions in Asia: APEC and ASEAN+3. Paper presented at the International Studies Association 48th Annual Convention, Chicago, IL, USA, 28 Feb 2007. Accessed at: http://www.allacademic.com/meta/p179422 index.html.

Lau E, Niu S, Tao V, Shang J, Gong P. 2014. China Industrials Sector, Investment Exploration on the New Silk Road, Citi Research, 17th November.

Mitty Steele, 2013, WBG World Bank Overview, created by Sara Gimmy on 2 Nov, http://portal.wko.at/wk/dok detail file.wk?angid=1\&docid=1986263\&conid=667632

2015, Silk Road Key to China's Next Move, 1 September, accessed at http://www.huffingtonpost.com/matthew-j-kiernan/silk-road-key-to-chinasn_b_8068318.html?ir=India\&adsSiteOverride=in

Nabers, D. 2008. Talking Regions into Existence: Institution-building in Asia and Europe. Paper presented at the ISA's 49th ANNUAL CONVENTION, BRIDGING MULTIPLE DIVIDES, Hilton San Francisco, San Francisco, CA, USA, 26 March 2008. Accessed online: http://www.allacademic.com/meta/p251101 index.html

Poole, A. 2008. Processes of Socialization in Regional Institutions: The Evolution of ASEAN Norms. Paper presented at the ISA's 49th Annual Convention, Bridging Multiple Divides, San Francisco, CA, USA, 26 Mar 2008. Accessed online: http://www.allacademic.com/meta/p251387 index.html

Schiavo-Campo, Salvatore and Pachampet Sundaram. 2000. To Serve And To Preserve: Improving Public Administration In A Competitive World. Manila: ADB.

Shimizu, S. 2007. The ASEM as a regional institution: A comparative regional approach between Europe and Asia. Paper presented at the International Studies Association 48th Annual Convention, Hilton Chicago, Chicago, IL, USA, 28 Feb 2007. Accessed online: http://www.allacademic.com/meta/p180876 index.html.

United Nations Economic and Social Commission for Asia and the Pacific (UNESCAP), 2010. UNESCAP Transport Division website, http//www.unescap.org/ttdw/coomon/TIS/ ALTID/Altid.asp 


\section{Appendix}

Figure 1: A New Institutional Framework for the Pan-Asian Infrastructure Connectivity

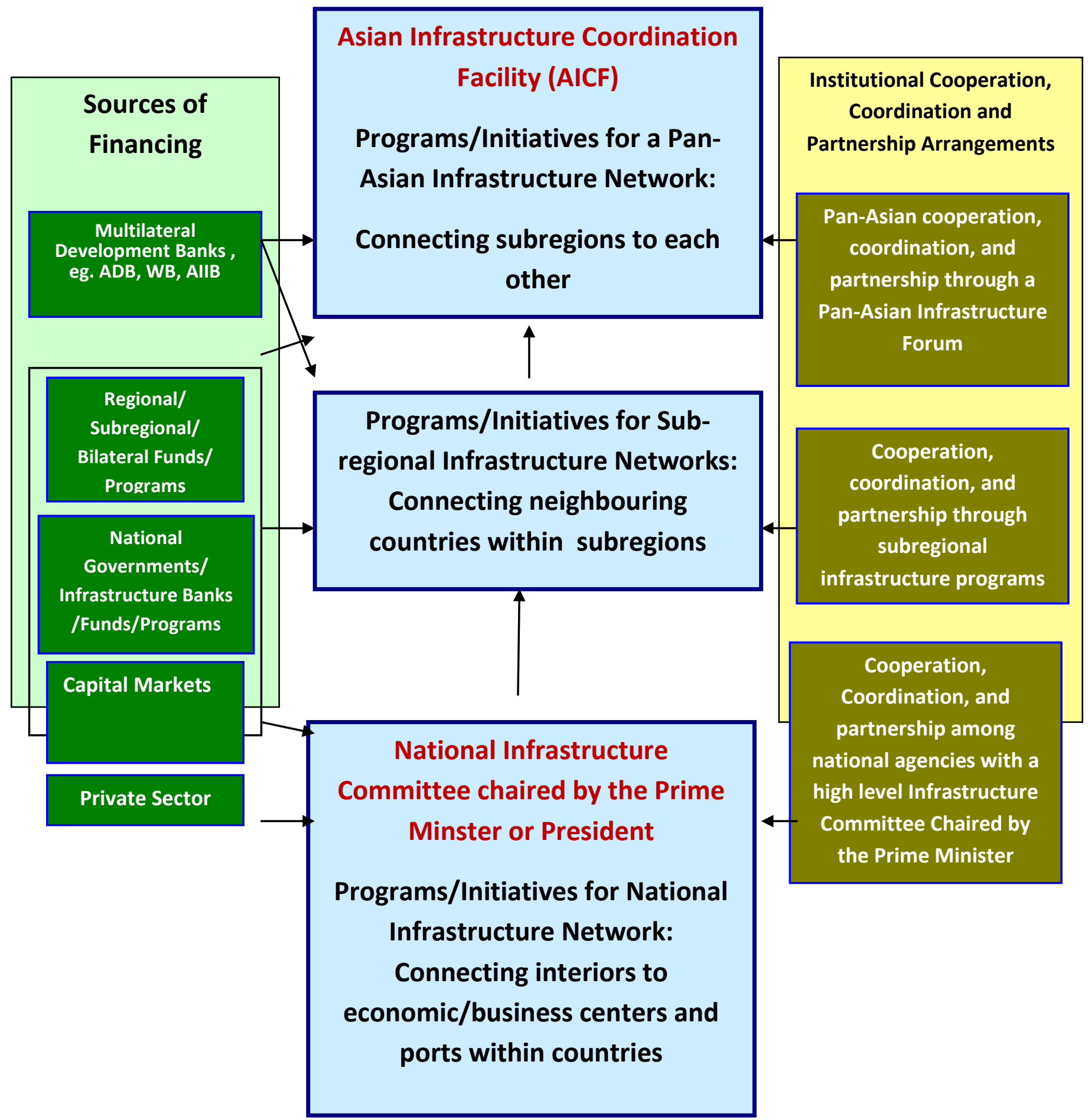


Figure 2: Institutional Framework for Asia Infrastructure Coordination Facility

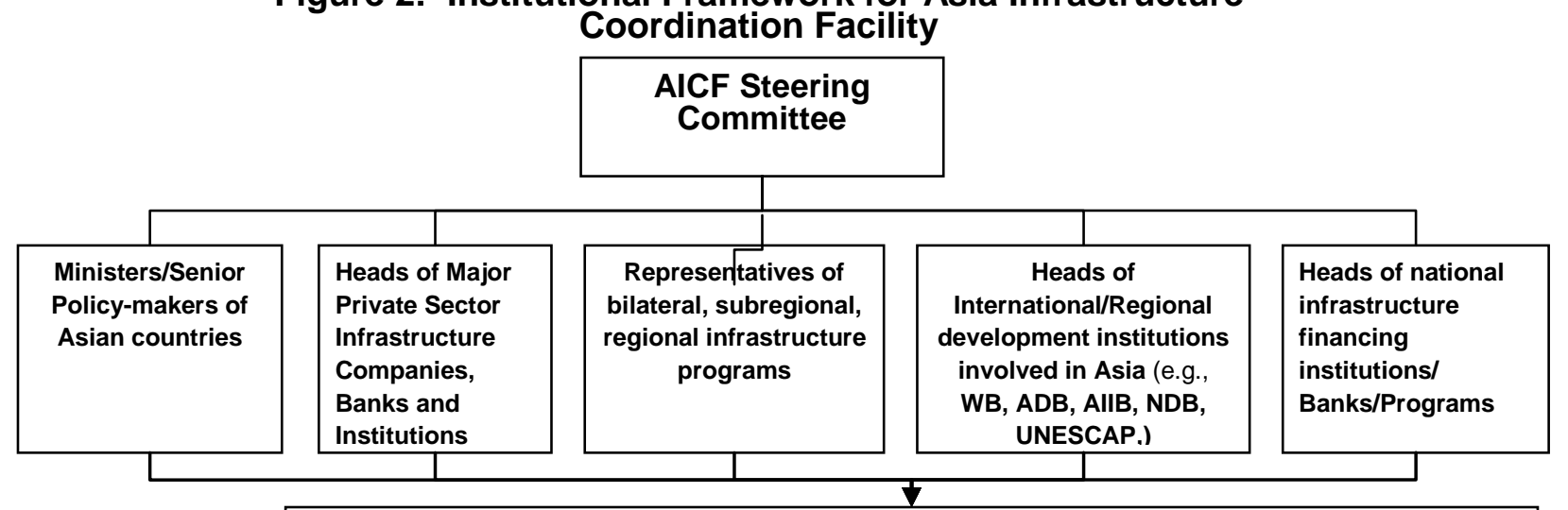

National infrastructure committee chaired by the Prime Minster or President (consisting of Heads of National Technical institutions on infrastructure Sectors)

Development of Sector-wise Pan-Asian Infrastructure Strategies and Polices Regionall

Subregional

Financing

Institutions and Programs

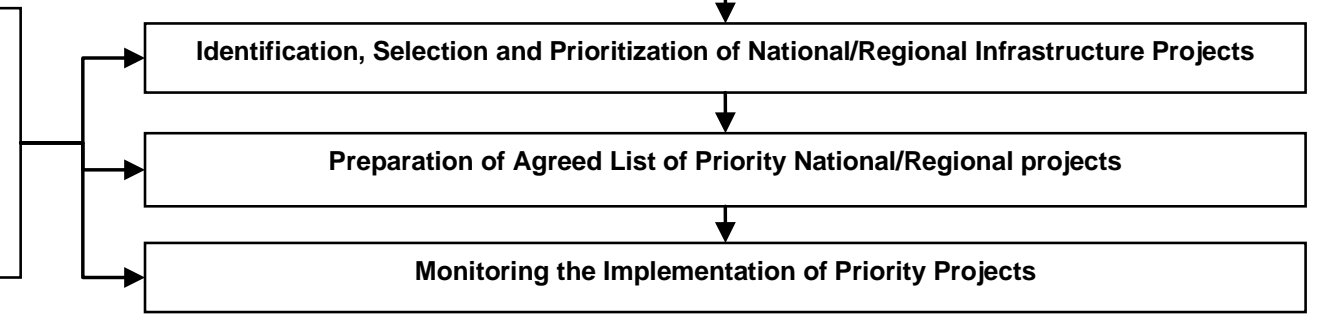

Sector-wise Strategies:

1. Energy Network (Power, Gas, and Oil);

2. Transportation Network (Roads, Rails, Seaports, and Airports);

3. Telecommunications Network (Landline, Mobile Phones, Internet); and

4. Water and Sanitation Network

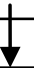


Figure 3: Organizational Structure of the AICF Secretariat

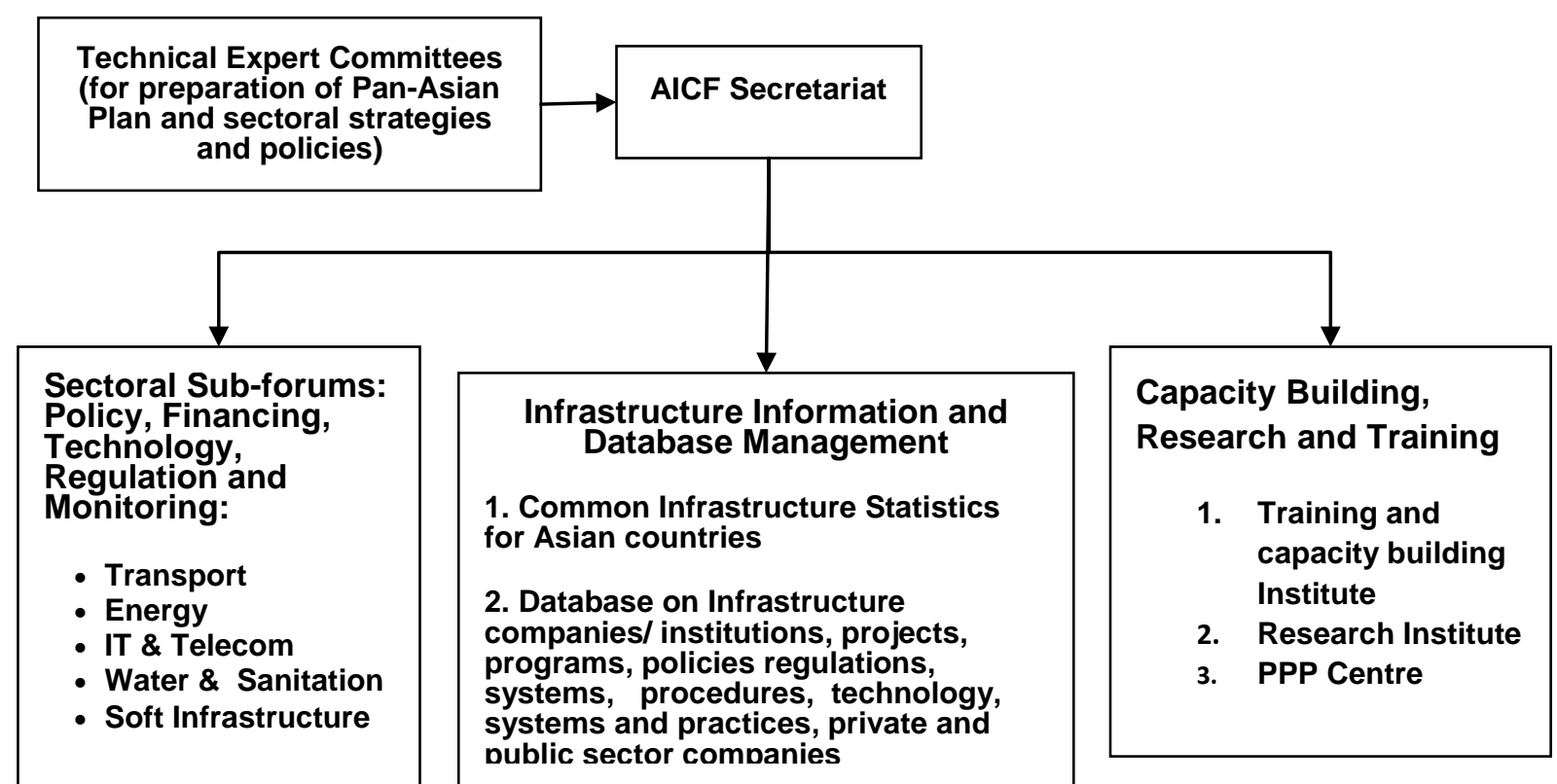

Source: Author 